\title{
BRICs' Philosophies for Development Financing and Their Implications for LICs
}

Nkunde Mwase and Yongzheng Yang 


\title{
IMF Working Paper
}

Strategy, Policy, and Review Department

\section{BRICs' Philosophies for Development Financing and Their Implications for LICs}

\author{
Prepared by Nkunde Mwase and Yongzheng Yang ${ }^{1}$
}

Authorized for distribution by Catherine Pattillo

March 2012

\begin{abstract}
Flows of development financing from the BRICs (Brazil, Russia, India, and China) to low income countries (LICs) have surged in recent years. Unlike aid from traditional donors, BRICs (excluding Russia) view their financing as primarily based on the principles of SouthSouth cooperation, focusing on mutual benefits without attachment of policy conditionality. This paper provides an overview of the philosophies and modalities of BRIC financing and examines their implications for LIC economies and future LIC-BRIC engagement.
\end{abstract}

JEL Classification Numbers: B3, F3, F5, O2, P5

Keywords: Aid, BRICs, Brazil, India, China, Russia, Institutions, Debt, LICs

\section{This Working Paper should not be reported as representing the views of the IMF.}

The views expressed in this Working Paper are those of the author(s) and do not necessarily represent those of the IMF or IMF policy. Working Papers describe research in progress by the author(s) and are published to elicit comments and to further debate.

Author’s E-Mail Address: nmwase@imf.org ; yyang@imf.org

\footnotetext{
${ }^{1}$ We would like to thank Catherine Pattillo, Dominique Desruelle, Hugh Bredenkamp, Montie Mlachila, Patrick Imam, and Therese Trasino for their useful comments. Production was assisted by Neri Gomes, Nazma Nunhuck, and Kate Jonah.
} 


\section{Contents}

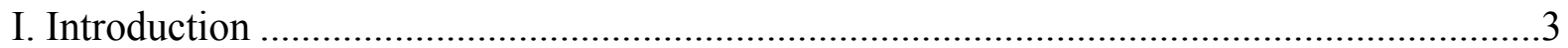

II. Philosophies and Modalities of BRIC Development Financing ....................................4

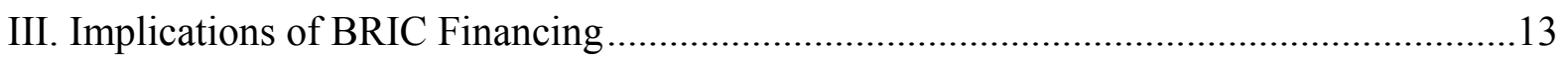

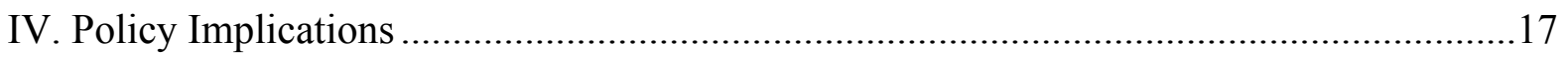

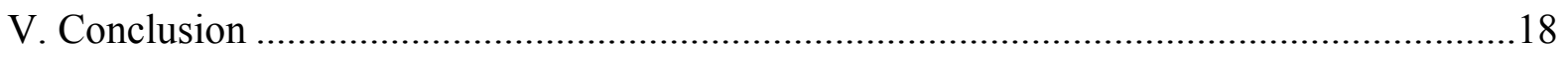

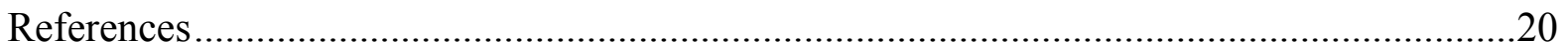

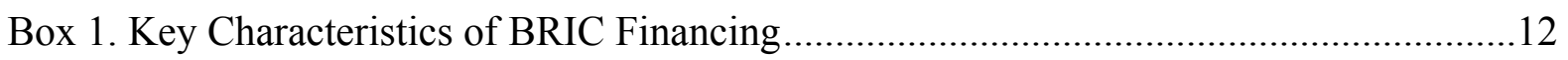




\section{INTRODUCTION}

BRIC financing to LICs is growing rapidly, driven mainly by China. ${ }^{2}$ In contrast with many industrial countries which are facing large fiscal consolidation and consequent challenges to meet their aid commitments, BRICs are in a strong position to continue increasing development financing. This paper contributes to the aid literature by examining the principles and modalities of BRIC financing, contrasting this with the main OECDDevelopment Assistance Committee (DAC) framework, and by drawing their implications for LIC economies and future LIC-BRIC engagement. While many of these challenges are not uniquely related to BRIC financing and have been discussed extensively in relation to the pros and cons of the approach taken by OECD donors, the rapidly growing BRIC financing has intensified the debate on aid effectiveness and related policy challenges.

BRICs' philosophies for development financing differ from those of "traditional donors" (OECD-DAC members) in three significant ways.

- $\quad$ BRIC engagement, with the exception of Russia, is founded on a model of mutual benefits. Most of the financing has been concentrated in the infrastructure sector to support productive activities. Russia, similar to traditional donors, has recently focused on social spending, seeing poverty reduction as the main objective of their ODA. $^{3}$

- $\quad$ Some BRICs, particularly China, tend to provide noncash financing for projects without attachment of policy conditionality. They view this as part of the principle of noninterference of internal affairs and as a means of circumventing corruption. In contrast, traditional donors view policy conditionality on institution building and governance as central to ensuring efficient use of aid.

- $\quad$ Concepts of debt sustainability differ, with BRICs tending to focus on microsustainability of individual projects while traditional donors pay greater attention to long-run debt sustainability by taking into account macroeconomic linkages.

Development financing provided by BRICs has helped LICs alleviate some key bottlenecks to domestic economic activity and boost exports but it has also posed a number of challenges. The concentration of BRIC financing in infrastructure could have large positive growth effects by addressing infrastructure deficits in LICs, raising productivity by reducing business costs for tradables and nontradables sectors alike, and supporting expansion in trade

\footnotetext{
${ }^{2}$ Although South Africa has recently joined the group, this analysis focuses on the original four countries: Brazil, Russia, India, and China.

${ }^{3}$ The traditional donor's shift from infrastructure investment to social spending was mainly driven by findings of weak project selection and implementation, resulting in "white elephants".
} 
and investment. However, concerns have been raised about the impact on debt sustainability, subsidized export credits received by some BRIC firms (Brautigam, 2010), and labor practices. These concerns highlight the need to ensure that development financing is used to promote sustainable and inclusive growth.

The rest of the paper is organized as follows. Section II describes the philosophies and modalities of BRIC financing. Section III examines the impact of BRIC financing, and Section IV discusses policy implications. Section V concludes.

\section{Philosophies ANd Modalities of BRIC DeVelopment FinanCing}

Although BRICs are usually referred to as emerging development partners, they have provided financial support to LICs since the 1950s, even at the time when some of them had lower GDP per capita than many LICs. Historically, Brazil, China, and India have provided assistance as part of South-South cooperation while Russia's engagement has been shaped by the Cold War era.

Most of the BRICs' philosophies related to development financing can be traced back to the South-South Cooperation discussions, which emphasize principles of equality, solidarity, and mutual development and complementarity. ${ }^{4}$ Drawing on these principles, most BRICs have increasingly emphasized the mutual benefits of cooperation, focusing on promoting trade, investment, and other commercial activities. ${ }^{5}$ Brazil, China, and India see themselves as 'development partners,' not 'donors'. ${ }^{6}$ Their experience as recipients of traditional develoment assistance and their identification with other recipients also contribute to their

\footnotetext{
${ }^{4}$ For the South-South Cooperation principles see http://www.g77.org/doc/Declaration2009.htm , para. 70, as reaffirmed in the Ministerial Declaration of the 33rd Annual Meeting of the Ministers of Foreign Affairs of the Member States of the Group of 77 and China, 25 September 2009, New York, USA.

${ }^{5}$ Though Brazil also uses the concept of partnership for development, it emphasizes that its cooperation efforts do not have a commercial purpose but is based on shared interests and mutual help. However, most observers have argued that Brazil's development assistance enlarges and strengthens Brazilian interests by opening new markets for its products and services (Vas and Inoue, 2007).

${ }^{6}$ Many LIC policmakers have welcomed the general BRIC approach in which their countries are viewed as an partner for trade and investment, not recipient of aid. See Paul Kagame (Presdient of Rwanda), "Why Africa welcomes the Chinese" at http://www.guardian.co.uk/commentisfree/2009/nov/02/aid-trade-rwanda-china-west. Nigerian and Zambian Ministers also made similar remarks at an IMF seminar "Commodity Price Volatility and Inclusive Growth", September 21, 2011 (http://www.imf.org/external/np/seminars/eng/2011/lic/index.htm) and an IMF panel discussion "BRICs: New Growth Drivers for Low-Income Countries?”, April 15, 2011 (http://www.imf.org/external/spring/2011/mmedia/view.aspx?vid=906001151001).
} 
sensitivity to the term 'aid'. 'Indeed, the term is sometimes contentious (e.g., China does not regard itself as providing aid). ${ }^{8}$

In addition, these BRICs do not attach conditions on governance, economic policy and performance, and institutional reforms to their cooperation.

- $\quad$ Conditionality, they argue, would undermine the principle of respecting "national sovereignty" and promoting "solidarity". ${ }^{9}$ China, in particular, emphasizes the respect of the national sovereignty (broadly defined to include national economic policies) of the recipient country. Partly reflecting China's own recent development history and its policy of noninterference, it believes that the long-term development of a country is ultimately the responsibility of the recipient and not the development partners' (Schiere, 2010).

- While traditional donors attempt to improve governance by attaching policy conditions to aid, China argues that "tied aid" (i.e., financing that is tied to purchases from the source country) helps circumvent this, lowering the risk of financial mismanagement and misappropriation of funds (see later discussion). Accordingly, China often extends credit lines in a special account where funds are channeled directly to firms (often of Chinese origin) contracted for projects, rather than to entities of the recipient country.

- While conditionality has often been criticized as intrusive and weakening country ownership of reforms, tied aid has reportedly not been able to address concerns about transparency and corruption (e.g., over-invoicing), especially given the general lack of comprehensive, meaningful, and timely statistics (see later discussions). ${ }^{10}$ This is consistent with findings that there is no significant positive relationship between aid allocations and institutions. ${ }^{11}$

Most of the BRIC development financing is concentrated in the infrastructure sector though there are some differences across BRICs. Chinese and Indian infrastructure financing to

\footnotetext{
${ }^{7}$ All BRICs, with the exception of Russia, have been aid recipients and some continue to receive aid from traditional donors.

${ }^{8}$ Brautigam (2010) and Vas and Inoue (2007).

${ }^{9}$ Brautigam (2010); The Reality of Aid Network (2010); and the Smith et al., (2010).

${ }^{10}$ Foster et al (2009), Huse and Muyakwa (2008).

${ }^{11}$ See Svensson (1999) and Alesina and Dollar (2000). In the case of BRIC financing, Mwase (2011) finds that LICs with weaker institutions tend to receive more BRIC financing, a result possibly reflecting the fact that commodity-exporters and post-conflict countries tend to receive more financing.
} 
Africa alone is now of similar magnitude to that from traditional donors. ${ }^{12}$ More recently, there has been a shift toward supporting investment in agricultural development, debt relief, and the expansion of preferential access (FOCAC, 2009; Foster et al., 2009; Infrastructure Consortium for Africa, 2008). BRICs have also provided other support to LICs, including technical assistance, research support, and training, especially in agriculture and health.

- For Chinese financing, “free assistance" (i.e., grants一无偿援助) and interest-free loans are offered mostly for construction of social infrastructure (e.g., stadiums, market squares, medical clinics and schools, and government complexes) while preferential loans and credit lines are provided for productive infrastructure, such as hydropower, water generation, and roads/railways. India's development financing is mostly in the form of grants, loans, and credit lines allocated to the agricultural and infrastructure sectors (electricity, hydropower, and railways).

- In contrast, Brazil and Russia's concessional financing has largely been provided through multilateral channels in the form of budget support (Russia) and project assistance (Brazil). Brazil tends to focus on technical assistance in education, agriculture, and health (Vas and Inoue, 2007). Research for development is a new element of Brazil's development assistance policy. Russia, like traditional donors, tends to focus on social spending to support poverty reduction initiatives. Most of Russia's financing is in the form of grants and debt relief.

- $\quad$ BRIC financing, particularly from China, often complements FDI and comes as part of a "package". Such a package tends to involve multi-year financing including grants, loans, and lines of credit with various participants. These various elements are intended to tackle multiple constraints on development and the "package" can be complex, especially when natural resource reserves are used as collateral. For example, under what has been coined the "Angola Model", Chinese financing is used to build a project, usually an infrastructure project; the project is often contracted to a Chinese company, which sources its supplies from China; a Chinese company acquires rights to a FDI project (e.g., mining), and invests in this project.

The difference in sectoral focus and modalities of financing partly reflects different domestic politics and BRICs' own experience as beneficiaries of aid.

- $\quad$ For traditional donors, the use of public funds for aid is often justified in the home country on the basis of poverty reduction, humanitarian assistance, or social welfare enhancement. Partly in reaction to concerns about aid effectiveness, the DAC donors,

\footnotetext{
${ }^{12}$ The Infrastructure Consortium for Africa (2008) estimates that in 2008 China provided US $\$ 11$ billion in infrastructure financing, while traditional development partners and the private sector, respectively contributed US\$13.7 billion and US\$15 billion.
} 
in 2001, agreed to virtually untie all aid to least developing countries (LDCs) and have been monitoring progress on this as part of the Paris Declaration (see later discussions). ${ }^{13}$

- $\quad$ For India and China, which are still lower middle-income countries - and still receive significant development assistance - the political economy supports mutual benefits that boost growth in India and China as well as recipient countries. ${ }^{14}$ The sectoral focus of the financing and use of tied aid partly reflects their own experience as recipients of aid: most of the aid the BRICs have received has been for investment projects and has helped alleviate infrastructure bottlenecks and poverty reduction. ${ }^{15}$ Some BRICs note that there has been an over-emphasis on "social projects" at the expense of building productive capacity and faster poverty reduction in the long run.

- $\quad$ Brazil's development assistance is coordinated by the Ministry of External Relations and follows development priorities established locally by cooperation partners. The provision of external cooperation is often justified as humanitarian assistance and poverty reduction, motivated by the objective of having a more balanced distribution of growth and wealth with its neighbors and countries with close cultural affinity. Brazil emphasizes that it engages in partnerships that can mutually benefit all sides in their development processes, and not for business or market access interests. ${ }^{16}$

These differences from traditional donors contribute to divergences in the way in which development assistance is delivered and how its effectiveness is assessed. They have also affected how BRICs coordinate with other development partners.

- China, and to some extent India, generally evaluates its assistance using two main yardsticks: cost competitiveness and completion time. The focus is bilateral government-to-government relations and projects tend to have shorter approval time than traditional donors who place greater emphasis on consultation process,

\footnotetext{
${ }^{13}$ However, Brautigam (2008) notes that although 54 percent of all OECD aid is tied today, this progress is very recent. In 2001 for example, the OECD reported that 92 percent of Italy's ODA was tied and about 68 percent of Canada's. Unlike other BRICs, Russia notes that about 75 percent if its aid is untied.

${ }^{14}$ India is the largest recipient of both concessional financing (IDA) and IBRD financing (World Bank, 2010). Rising levels of per-capita income during the 1990s enabled Brazil to complete the transition from a recipient to a provider of development assistance.

${ }^{15}$ Reflecting the aid ideology at the time, 80 percent of total lending portfolio of the World Bank during the period 1948-1960 (roughly US\$2.9 billion) was for power and transportation. From the 1950s onwards, Japan signed agreements with India then later China that provided concessional financing, technical training, and necessary equipment in exchange for assured access to important raw materials. According to Chaturvedi (2008), in 1987, almost US\$9 billion in aid was provided by the OECD-DAC members to recipient countries for construction projects, of which 63 percent was tied to purchases from the donor countries.

${ }^{16}$ Cooperação Bilateral com América Latina e Caribe (Publication of the Brazilian Agency for Cooperation, June 2, 2006; see http://www.abc.gov.br/noticias/banco_noticias.asp?id_Localizacao=3).
} 
feasibility studies and social and environmental safeguards. However, the sustainability of some of these projects, like many OECD-DAC financed projects, have often come under pressure due to lack of maintenance. ${ }^{17}$

- $\quad$ Russia and Brazil, like the traditional donors, prefer to coordinate positions with civil societies and other stakeholders to foster broad national ownership of policies. Traditional donors have increasingly emphasized the importance of channelling aid through the budget of the recipient country, to avoid competition and duplication and to build governance standards. ${ }^{18}$ Toward this end, traditional donors are now paying more attention to budget controls and internal audit and procurement standards (Easterly et al., 2004; Roodman, 2006; and Schiere, 2010). ${ }^{19}$

- The traditional donors have emphasized the importance of harmonization and coordination to improve aid effectiveness and efficiency. Through the Paris Declaration and Accra Agenda for Action, the traditional donors have committed to a framework for development assistance involving country-owned systems (for recipients), the untying of aid and reducing the number of project implementation units, noting that weaknesses in these areas contributed to aid ineffectiveness in the 1980s. While all BRICs have "endorsed" the Paris Declaration, most of them perceive that their endorsement of the Paris principles is in their capacity as recipients of aid (Chaturvedi, 2008). BRICs and other emerging donors have argued that the current multilateral system (including their limited voice) is not configured to provide sufficient incentives for them to engage in it.

The differences have also led to divergences in the concept of debt sustainability and debt relief between some BRICs and traditional donors.

\footnotetext{
${ }^{17}$ China argues that maintenance, just like long-term development, is the responsibility of the recipient. Similarly, traditional donors and multilateral development agencies are also reluctant to provide funding for maintenance, as the implied infinite financing would create a moral hazard problem.

${ }^{18}$ There has been a significant increase in disbursement of aid as budget support to least developed countries from US\$2 billion in 2002 to US\$3.9 billion in 2009, but as a proportion of aid to LDCs, budget support has actually declined from 12 percent to 9.1 percent in 2009. (Disbursement data are not available prior to 2002). Moreover, even in LDCs that receive a sizeable amount of aid as budget support, the shares are still relatively low. Specifically, eight LICs received nearly a fifth or more of their aid as budget support in 2009 (Burkina Faso 23 percent, Democratic Republic of Congo 33 percent, Guinea Bissau 22 percent, Mozambique 23 percent, Rwanda 18 percent, Sierra Leone 19 percent, Tanzania 32 percent, and Zambia 37 percent). LDCs with the lowest shares of budget support include post-conflict economies partly reflecting donor concerns about disbursing directly to these governments' budgets (DCF, 2011).

${ }^{19}$ The traditional development partners are not a homogenous group, some countries are not altogether supportive of budget support.
} 
- $\quad$ China and India generally focus on a project's economic viability while traditional partners emphasize long-term debt sustainability at the economy-level (Anshan, 2007b, Reisen and Ndoye, 2008). China makes a distinction between productive and nonproductive investments; the latter are generally financed through grants while the former generally by loans. The Chinese authorities argue that loans for productive investments are expected to repay themselves, as they are selected based on project-by-project feasibility studies that identify those that are highly profitable. For example, a loan to support railway investment would be expected to increase the recipient's ability to repay loans. In contrast, traditional partners pay more attention to debt sustainability at the macroeconomic level, often based on the results of the IMF/World Bank Debt Sustainability Analysis, which also takes into account the recipient's ability to repay based on fiscal revenue that the project would generate. More recently, some Chinese officials have acknowledged the importance of taking into account macroeconomic linkages but argued that the IMF and World Bank often underestimate investment-induced growth, noting that higher investment is critical for LICs to achieve high and sustainable economic growth (see Li, 2008 and 2007).

- Whilst BRICs have provided debt relief, they have generally, with the exception of Russia, used their own frameworks. Russia is a member of Paris Club and has agreed to provide debt relief under the HIPC framework for eligible countries while Brazil and India participate on a case-by-case basis. ${ }^{20}$ China has provided debt relief independently, albeit often in parallel with the HIPC Initiative, including nonconditional debt cancellation to some countries that were pre-decision point with weak governance and macroeconomic instability. ${ }^{21}$

Development financing flows from BRICs, like traditional donors, are largely driven by natural resources, proximity, and cultural-language ties. ${ }^{22}$ Some of the largest financing

\footnotetext{
${ }^{20}$ Brazil is an associated member of Paris Club and participates in some negotiation sessions. India announced, in June 2003, its intention to write off all nonexport credit claims on HIPCs, but several agreements remain unsigned.

${ }^{21}$ Brautigam and Gaye (2007) and Sautman and Hairong (2009) note that China regularly cancels African loans, usually extended at zero interest, without questionable conditionalities required by OECD-DAC donors. In some cases, China has provided debt relief that exceeds the HIPC initiative. During the FOCAC meeting in 2000, China announced a debt write-off of RMB 10.9 billion that was owed by 31 African HIPC countries and LDCs. In 2005, it was announced that all zero-interest loans to HIPCs that was overdue by end-2004 would be either written off or forgiven. As a part of the Beijing Action Plan, China has pledged to write off the interestfree loans due end-2005 of all African HIPC countries which have diplomatic relations with China (Huse and Muyakwa, 2008; FOCAC, 2000; and IDA\&IMF, 2007). It has not cancelled debt for three HIPCs (Burkina Faso, São Tomé and Principé, and The Gambia) that switched diplomatic recognition to the Taiwan Province of China during the 1990s (Brautigam, 2010).

${ }^{22}$ See Mwase (2011) for an empirical assessment of the determinants of BRIC financing flows to LICs.
} 
flows, in absolute terms, to Africa from BRICs are in countries with natural resources. This pattern is similar to that of traditional donors. Flows from Brazil to LICs are heavily concentrated in Portuguese-speaking countries, reflecting shared colonial ties bolstered by cultural and historical affiliations. ${ }^{23}$ Similarly, Russia provides a sizable share of its financing to neighboring former Soviet economies. Most of India's assistance is provided to neighboring countries. China's financing is much more diverse. In Africa, it spreads to all countries except Swaziland, which still maintains diplomatic ties to Taiwan, Province of China. However, nearly 70 percent of China's infrastructure financing in Africa is reportedly concentrated in four countries (Angola, Nigeria, Ethiopia, and Sudan), all of which have oil fields (Lum et al., 2009). Empirical evidence indicate that linguistic and colonial ties influence the allocation of OECD aid and that proximity to the OECD donors enhances the share of aid a country receives (Round and Odedokun, 2004).

Philosophical differences between traditional donors and some BRICs contribute to differences in concepts and thus estimates of BRIC development assistance. Most BRICs include all development support (including loans that have below-market interest rates) that is designed to help countries grow, while the OECD definition excludes nonconcessional assistance. ${ }^{24}$ Whilst an important share of traditional donors financing is humanitarian assistance, this is excluded in China's development assistance data as it is considered a "stopgap" measure to prevent excessive suffering as opposed to development (Davies $e t$ al., 2008, 2010). ${ }^{25}$ Estimates of BRIC "aid" and comparisons with traditional donors therefore need to be treated with caution as the limited BRIC data that is provided is not readily comparable with DAC data.

There is a general lack of comprehensive, meaningful, and timely statistics by both BRICs and recipient countries. Different reasons have been given for the lack of data. For China, for example, the political sensitivity of helping LICs while China has a large poor population and the Chinese culture of not publicizing a debtor's details is cited (Brautigam, 2010). However, discussions with recipients suggest that they too are often not fully apprised of the terms of the financing.

BRICs' development assistance programs are implemented through a range of different agencies. This appears to reflect the evolving nature of their programs. The key

\footnotetext{
${ }^{23}$ The target countries defined primarily by Brazil's foreign policy priorities (including non-LICs) have been identified as Mercosur countries in South America, the Portuguese-Speaking Community of Countries (CPLLP) (Angola, Guinea Bissau, Cape Verde, Mozambique, and East Timor), and African countries such as Nigeria.

${ }^{24}$ For example, most of the Chinese and Indian cooperation is 'in kind' but there is no standard accounting framework to capture this flow (Wang, 2007). In addition, there is also potential for some downward bias when comparing with ODA as some BRICs (e.g., China) do not include the entire face value of a concessional loan but only reflect the grant component.

${ }^{25}$ Chinese humanitarian assistance is managed by the Ministry of Social Welfare.
} 
characteristics and modalities of BRIC financing, along with various agencies that are responsible for policies and program implementation, are summarized in Box 1.

- China has three central institutions that are involved in development assistance- the Ministry of Commerce (MoFCoM), China Exim Bank, and the Ministry of Foreign Affairs (Brautigam, 2010; and Chaturvedi, 2008) ${ }^{26} \mathrm{MoFCoM}$ in general takes the lead on China's official assistance policy. China's EXIM bank and the China Development Bank (CDB) provide preferential/concessional loans and export credits for the purchase of Chinese goods and services..$^{27}$ The Ministry of Finance allocates donations to multilateral organizations and manages debt cancellation. Over 20 line ministries, state-owned banks, and other agencies are also involved in administering development assistance activities often without central coordination. ${ }^{28}$

- The Indian government announced, in 2007, that it would set up a lead agency to coordinate development cooperation - the India International Development Cooperation (IIDC). From an organizational perspective, the Ministry of External Affairs (MEA) no longer has a monopoly on all instruments of aid policy whilst the influence of the Ministry of Commerce in aid allocation has grown (Chaturvedi, 2008). Various ministries and institutions would be also represented in the IIDC, including the Ministry of External Affairs (MEA). ${ }^{29}$

- $\quad$ Brazil has a dedicated agency (the Brazilian Cooperation Agency (ABC)) for development cooperation that is housed in the Ministry of External Relations (MRE). The MRE is responsible for articulating the actions of the ministries engaged in development assistance (in particular, Ministries of Education, Health, Agriculture, and Science and Technology) to ensure they are in line with foreign policy priorities. The role of the $\mathrm{ABC}$ is to negotiate, promote, and monitor the Brazilian government's technical cooperation projects and programs ${ }^{30}$ The $\mathrm{ABC}$ controls three forms of

\footnotetext{
${ }^{26}$ The State Council (China's cabinet, headed by the premier) has an oversight role for development assistance. It approves the annual development assistance budget, any grants of cash above US $\$ 1.5$ million, all aid projects above 100 million RMB (about US\$12.5 million), assistance to "politically sensitive countries" and any requests to exceed the annual plan for foreign assistance (Brautigam, 2010).

${ }^{27}$ EXIM bank is the dominant lender. CDB accounts for only 21 percent of total loans to developing countries (Gu, 2007).

${ }^{28}$ The Forum on China-Africa Cooperation, for example, is driven by the MoFCoM-which is in charge of facilitating grants and loans to African countries - and is supported by the Ministries of Finance and Foreign Affairs and embassies in African countries.

${ }^{29}$ MEA still has various institutional arrangements under its wings, such as the Indian Technical and Economic Cooperation (ITEC), Aid to African countries through Special Commonwealth Assistance Program for Africa (SCAAP), Bilateral Aid to neighboring and other developing countries (Vijava et al., 2009).

${ }^{30}$ While the agency is guided by core principles, it does not always adhere to foreign policy priorities (Vas and Inoue, 2007).
} 
international cooperation: programs for technical cooperation in developing countries (TCDC), bilateral, and multilateral technical cooperation. Several Brazilian organizations are engaged in TCDC as project implementers.

Box 1. Key Characteristics of BRIC Financing

\begin{tabular}{|c|c|c|c|c|}
\hline & Brazil & Russia & India & China \\
\hline $\begin{array}{l}\text { Key } \\
\text { agency }\end{array}$ & $\begin{array}{l}\text { Brazilian } \\
\text { Cooperation } \\
\text { Agency }(\mathrm{ABC})\end{array}$ & $\begin{array}{l}\text { Department of } \\
\text { International Finance }\end{array}$ & $\begin{array}{l}\text { Indian International } \\
\text { Development Cooperation } \\
\text { Agency (IIDCA) was proposed } \\
\text { in } 2007 \text { but has not been } \\
\text { established. }\end{array}$ & $\begin{array}{l}\text { No such agency yet, but discussions } \\
\text { to establish one are continuing. }\end{array}$ \\
\hline $\begin{array}{l}\text { Key } \\
\text { Ministry }\end{array}$ & $\begin{array}{l}\text { Ministry of External } \\
\text { Relations }\end{array}$ & $\begin{array}{l}\text { Ministry of Finance and } \\
\text { Ministry of Foreign } \\
\text { Affairs. }\end{array}$ & $\begin{array}{l}\text { Ministry of External Affairs } \\
\text { (MEA) }\end{array}$ & $\begin{array}{l}\text { Department of Aid in Ministry of } \\
\text { Commerce }\end{array}$ \\
\hline $\begin{array}{l}\text { Other } \\
\text { Agencies }\end{array}$ & $\begin{array}{l}\text { EMBRAPA, } \\
\text { FIOCRUZ, } \\
\text { FARMANGUINHO } \\
\text { S, SENAI, } \\
\text { SEBRAE, CAPES, } \\
\text { FINEP, CNP. }\end{array}$ & $\begin{array}{l}\text { Federal Executive } \\
\text { Authorities. }\end{array}$ & $\begin{array}{l}\text { EXIM Bank, Indian Council for } \\
\text { Cultural Relations, and other } \\
\text { respective Ministries }\end{array}$ & $\begin{array}{l}\text { Ministry of Finance, Ministry of } \\
\text { Foreign Affairs; Exim Bank; China } \\
\text { Development Bank and other } \\
\text { agencies. }\end{array}$ \\
\hline Form & Loans and grants & $\begin{array}{l}\text { Mostly grants (to } \\
\text { international IDA funds } \\
\text { and programs) and debt } \\
\text { relief. }\end{array}$ & $\begin{array}{l}\text { Grants, credit lines, interest-free } \\
\text { loans and other concessional } \\
\text { and nonconcessional loans }\end{array}$ & $\begin{array}{l}\text { Grants, credit lines, interest-free loans } \\
\text { and other concessional and } \\
\text { nonconcessional loans }\end{array}$ \\
\hline Modality & $\begin{array}{l}\text { Mostly through } \\
\text { multilateral } \\
\text { channels. Co- } \\
\text { financed projects } \\
\text { and technical } \\
\text { assistance }\end{array}$ & $\begin{array}{l}\text { Mostly through } \\
\text { multilateral channels in } \\
\text { the form of untied } \\
\text { voluntary contributions. }\end{array}$ & $\begin{array}{l}\text { Mostly project-oriented with the } \\
\text { exception of Bhutan, Nepal and } \\
\text { Afghanistan, debt cancellation, } \\
\text { and humanitarian assistance }\end{array}$ & $\begin{array}{l}\text { Mostly projects, in-kind, technical } \\
\text { cooperation and debt relief. }\end{array}$ \\
\hline $\begin{array}{l}\text { Official } \\
\text { aim }\end{array}$ & $\begin{array}{l}\text { South-south } \\
\text { cooperation; } \\
\text { mutual economic } \\
\text { development, and } \\
\text { strengthen cultural } \\
\text { relations }\end{array}$ & $\begin{array}{l}\text { Sustainable Poverty } \\
\text { Reduction }\end{array}$ & $\begin{array}{l}\text { South-south cooperation, } \\
\text { regional stability and access to } \\
\text { markets and resources, and } \\
\text { strengthen cultural relations }\end{array}$ & $\begin{array}{l}\text { South-south cooperation and access to } \\
\text { markets and resources }\end{array}$ \\
\hline $\begin{array}{l}\text { Country } \\
\text { focus }\end{array}$ & $\begin{array}{l}\text { Latin America and } \\
\text { African countries } \\
\text { (especially } \\
\text { Lusophone) }\end{array}$ & $\begin{array}{l}\text { Mostly CIS countries, (in } \\
\text { particular, Kazakhstan } \\
\text { and Kyrgyzstan). }\end{array}$ & $\begin{array}{l}\text { Immediate neighborhood (e.g., } \\
\text { Afghanistan, Bhutan, Burma } \\
\text { and Nepal), and Africa }\end{array}$ & $\begin{array}{l}\text { Widespread though large amounts } \\
\text { concentrated in a few countries }\end{array}$ \\
\hline Sector & $\begin{array}{l}\text { Mostly agriculture, } \\
\text { education and } \\
\text { health. }\end{array}$ & $\begin{array}{l}\text { Mostly general budget } \\
\text { support. }\end{array}$ & $\begin{array}{l}\text { Grants mostly rural } \\
\text { development, education, health, } \\
\text { technical cooperation, loans for } \\
\text { infrastructure and disaster relief. }\end{array}$ & $\begin{array}{l}\text { Mostly energy, transport and } \\
\text { communications, but also construction } \\
\text { of schools and hospitals, and prestige } \\
\text { projects (e.g., stadiums) }\end{array}$ \\
\hline
\end{tabular}

Source: Chaturvedi, 2008; Vijava et al., 2009; Kragelund, 2010; The Reality of Aid Network, 2010; Russian Authorities, 2006, and Russia's G8 Presidency, 2006. 


\section{IMPLICATIONS OF BRIC FINANCING}

Given the lack of data, it is difficult to quantify the macroeconomic impact of recent BRIC scale-up in financing. We therefore provide a qualitative analysis of the potential impact.

The scaling up of public investment associated with most BRIC financing is likely to have large positive growth effects.

- $\quad$ BRIC financing could help many LICs address their infrastructure deficits. The World Bank estimates that Sub-Saharan Africa (SSA) requires in excess of US\$93 billion per year - about 15 percent of the region's GDP or for SSA LICs, 22 percent of GDP - for infrastructure to begin reaching the level of other developing countries in Asia and Latin America (Foster and Briceño-Garmendia, 2010; Calderon, 2009; Freemantle and Stevens, 2010). Aid commitments from traditional donors would not be sufficient to meet these financing needs partly given the scale of the financing required and the recent focus of many bilateral donors on social sectors. Though some LICs have been able to borrow internationally, most continue to experience difficulties in accessing capital markets and have very low domestic savings.

- Indeed, BRIC financing has played an important role in alleviating infrastructure bottlenecks in many LICs and should help them tap their natural resources. ${ }^{31} \mathrm{~A}$ number of studies note the benefits of such financing - for example, it has resulted in a 35 percent improvement in electricity supply (including 6,000 megawatts of hydropower), a 10 percent increase in rail capacity and reduced the price of telephone services (Foster et al. 2009; Onjala, 2008). At least 35 countries in SSA, for example, have benefited from or are actively discussing Chinese infrastructure finance (Doemeland et al., 2010).

- $\quad$ Empirical studies suggest that these improvements could boost growth. Two recent surveys of the empirical literature (Agénor et al. (2006) and Straub (2008)) conclude that the majority of studies, covering a broad range of countries, find that the stock of infrastructure assets has a positive impact on the rate of economic growth, with the largest impact coming from telecommunications, roads, and electricity networks. For SSA, the World Bank estimates that increasing the stock and quality of infrastructure to Mauritius' level would have a growth payoff of 2.3 percent a year, with most of this coming from more-rather than better-infrastructure (Calderon, 2009).

- The scaling up of investment could also improve external competitiveness by raising productivity. The aid literature has noted that surges in aid flows could have adverse

\footnotetext{
${ }^{31}$ Collier (2010) notes that the lack of appropriate infrastructure has been a key reason why natural resources in SSA countries are left relatively untouched by traditional investors.
} 
effects on export competitiveness - raising demand for nontradables and inducing inflationary and appreciation pressures. ${ }^{32}$ However, to the extent that BRIC financing of infrastructure reduces the domestic costs of production and increases the productivity, there could be positive supply side effects that could improve export competitiveness. ${ }^{33}$ For example, an improved road network coupled with investments in agriculture would be expected to have a large positive impact on agricultural exports. Adam and Bevan (2006) find that beyond the short-run — when demand-side Dutch disease effects are present— public infrastructure investment that generates a productivity bias in favor on nontradable production delivers the largest aggregate return to aid..$^{34}$

- $\quad$ BRIC financing can help strengthen regional trade linkages. For instance, the rehabilitation of the Benguela railway line should facilitate trade between Angola, the Democratic Republic of Congo and Zambia, and exports from the mineral belt of Congo and Zambia; and the building of rail and port facilities in Liberia may facilitate the export of iron ore in both Liberia and Guinea.

- $\quad$ The strong focus of BRIC financing in improving access to trade and natural resources has been associated with a sharp increase in trade flows and foreign direct investment between LICs and BRICs (Mlachila and Takebe, 2011; Riad, forthcoming). Moreover, even Russia, which has substantial mining resources, has seen a surge in bilateral Russia-Africa trade. ${ }^{35}$ Indeed, in the context of the recent global contraction, LICs exporting to fast-growing emerging countries are expected to have a stronger trade-pull recovery than those whose exports depend more on

\footnotetext{
${ }^{32}$ Empirical evidence has been somewhat mixed. Rajan and Subramanian (2008) and Prati and Tressel (2006) find substantial real exchange rate appreciation effects using large cross-country panels. However, Nyomi (1998) and Sackey (2001) find that aid inflows lead to real exchange rate depreciation in Tanzania and Ghana, respectively (even in the short-run). This suggests that in some countries the offsetting productivity effects kick in very quickly. Atingi-Ego (2005) suggests that these findings could be driven by excess capacity in the nontradable sector which offset the impact of increases in demand on prices.

${ }^{33}$ Some recent studies find no evidence that trade between China and Africa has improved total factor productivity in Africa and argue that such trade can make Africa worse off (Elu and Price, 2010; Geda and Meskel, 2008; and Githinji, 2010). There are considerable methodological and data challenges in such research. For example, regressing firm-level productivity on country-level trade with China overlooks many other factors that may affect firm-level productivity and it is not obvious that the results have any economy-wide welfare implications.

${ }^{34}$ Increased productivity in nontraded goods sector can offset the standard relative price effect, at least in the steady state, and investment in the traded goods sector can offset any remaining contractionary effect there. It remains an empirical question how long it takes to reach the steady state, how much real appreciation there is before the steady state is attained, and how much of a productivity loss there is during the transition period.

${ }^{35}$ Exports to Russia have come mainly from North Africa (mostly fruits), West Africa (Guinea and Ivory Coast's aluminum and cocoa), and South Africa (iron and fruits), (Freemantle and Stevens, 2009).
} 
advanced-economies' demand (IMF, 2010). More generally, Samake and Yang (2011) find significant growth spillovers from BRICs to LICs both through direct channels (such as bilateral trade) and indirect channels (such as global commodity prices).

- $\quad$ BRIC assistance has been by and large complementary to aid from traditional donors. The different sectoral concentration of BRICs and traditional donors could help LICs obtain both critical financing for infrastructure as well as aid for poverty alleviation.

While BRIC financing has generated significant economic benefits for LICs, it also poses challenges that call for better economic management to minimize the associated risks and expand future benefits.

- A key challenge for LICs in managing their engagement with BRICs is to ensure sustainable debt in the long run, avoiding a repeat of past debt problems. Both LICs and BRICs need to take a prudent approach in evaluating the impact of increased financing on growth and debt burdens. While high project returns are essential to ensure debt sustainability at the macroeconomic level, they do not automatically lead to sufficient fiscal revenue to repay the associated debt. With their recent scaling up of lending, BRICs are no longer marginal players and it would be in their own interest, as well as those of recipient countries, to pay greater attention to the macroeconomic impact of financing on recipient countries. At the same time, any debt sustainability analysis, such as that undertaken by the IMF and World Bank needs to adequately take into account the impact of lending on growth as well as debt accumulation. Inadequate appreciation of the growth impact would deprive LICs of much needed investment for growth and poverty reduction while failures to assess the impact on the overall debt situation could risk long-term macroeconomic stability. For such an approach to be effective, there is a need for greater transparency on debt data, both by the BRICs and recipient countries.

- $\quad$ LIC-BRIC engagement could increase the risk of some LICs' long-term resource dependence though natural resources can also be used as lynchpin for growth. These LICs face a dilemma: while they would like to see better terms of trade resulting from higher commodity prices, the associated real exchange rate appreciation could reduce the competitiveness of noncommodity exports. Goldstein et al. (2007) argue that the emergence of China and India has reinforced Africa's comparative advantage in the production of resource-based commodities and the continent now runs a greater risk of falling into a commodity trap. ${ }^{36}$ Yang (2011), however, emphasizes that reliance on

\footnotetext{
${ }^{36}$ It is worth noting that many African countries are net commodity-importers and are worse off from higher commodity prices. It is not clear that these countries would now have a better chance to diversify into noncommodity exports, at least in the short run.
} 
natural resources is often a phase of development process that many developing countries have been through and that the way forward is to make best use of such resources to lay foundation for sustained, diversified growth.

- $\quad$ Some BRIC export credits could create a nonlevel playing field with BRIC firms being able to access financing at significantly lower cost through subsidized export buyer credits to the detriment of local manufacturers (Brautigam, 2010). The entrance of BRIC firms has increased competition in LICs and benefited the consumers and intermediate input users, partly reflecting their lower production costs (Tull, 2006). There is concern, however, that such competition has been associated with closure of some indigenous manufacturing companies in Africa (De Lorezo, 2007).$^{37}$ To the extent that the lower costs reflect the impact of concessional export buyer credits this could be perceived as export subsidy protecting the donor's firms at the expense of the local firms and external competitors from other countries (World Bank, 1991). For example, the China-Africa Development Fund (CADF) was set up to assist Chinese enterprises and entrepreneurs to invest in Africa. Whilst this could stimulate investment in Africa, it could create an unlevel playing field with African investors. ${ }^{38}$

- $\quad$ Concerns over labor practice are becoming an important issue and could fuel discontent in communities that see limited benefits to local employment and the economy (Anshan, 2007a). For example, the use of Chinese labor, rather than local workers in China-sponsored projects in Angola, Ethiopia, Sudan, Namibia, and Zambia has been criticized locally (Alden, 2005, Kiala, 2010). There is concern that the Chinese model for infrastructure development in Africa limits employment opportunities for locals (Kiala, 2010), and to the extent that a significant share of labor in BRIC projects is imported, the direct benefits for the local population are reduced. Data on labor usage in the recent projects is limited but early indications point to very diverse practices and experiences, with some Chinese construction companies in countries like Tanzania reporting about 80 percent of employment going to local communities whilst those in post-conflict countries (e.g., Angola and Sierra Leone) reporting much lower levels due to the lack of available skilled manpower (King, 2006). From the perspective of some BRICs, they often see local regulations as impediments to hiring local workers, and under-developed skills as making local workers more expensive than imported workers (Foster, 2009). They argue that expectations of local wages should be in line with labor productivity to ensure viable investment. The Chinese authorities note that their history of engagement with LICs demonstrates their willingness to utilize local labor-e.g., the

\footnotetext{
${ }^{37}$ De Lorezo (2007) notes that Chinese competition has had an adverse impact on African enterprises and exports; in Nigeria, imported textiles have forced local factories to close.

${ }^{38}$ CADF's direct capital and other domestic companies' investments facilitated by it accounted for more than 30 percent of the country's combined investments in Africa during 2009. The CADF is government-backed.
} 
Tanzania-Zambia (Tazara) Railway is viewed as a success partly because it symbolized locals and Chinese people working together side by side (Monson, 2006). ${ }^{39}$

\section{Policy Implications}

While the benefits from BRIC financing are significant, there are real challenges in managing risks associated with these inflows. The policy issues raised by BRIC financing are not new; similar issues arose in the past in relation to aid from traditional donors. Nevertheless, given the recent scaling up of BRIC financing and some of its unique characteristics, it is worth highlighting some of the key policy issues.

- $\quad$ Ensuring high returns on projects. As with other sources of financing, it is critical that LICs align BRIC-financed projects with national development priorities. The concentration of BRIC financing in infrastructure is encouraging, ${ }^{40}$ but this in itself does not guarantee high returns. ${ }^{41}$ An appropriate process of project selection (including through feasibility studies), implementation, and maintenance needs to be put in place to ensure desired outcomes. ${ }^{42}$ More generally, sound public investment management is key to translating infrastructure spending into sustained economic growth.

- Improving transparency and governance. Efforts should be made to improve data on the size and terms of financing flows, the structure and conditions of packaged deals, as well as the rights of concessions for natural resources. This could also help address some of the concerns about accountability and "imprudent" lending/borrowing to/by LICs. ${ }^{43}$ This is in the interest of both LICs and their development partners. On the cost side, competitive bidding for projects would help ensure that financing costs are sourced in a transparent and fair manner. Participation in some existing international

\footnotetext{
39 To support local skill development following the rail link's completion, it was reported that 200 Tanzanians and Zambians were to undergo a four-year training program beginning in August 1971 (Yu, 1971).

${ }^{40}$ The Commission for Africa (2005) and UN Millennium Project (2005) note that whilst achievement of MDGs, such as universal primary education is important, it is markets, trade, transport, investment, and infrastructure that make it profitable for enterprises to explore new products and technologies.

${ }^{41}$ Mwase $(1987,1983)$ notes that less than five years after it was completed, the performance of the iconic Tazara Railway suffered from amongst other issues, lack of maintenance.

${ }^{42}$ This includes grant-financed projects as these tend to have counterparty local co-financing and require future maintenance they could undermine countries' fiscal positions (Mwanawina, 2008; African Center for Economic Transformation, 2009).

${ }^{43}$ Ongoing efforts to strengthen statistics and management systems would also help these BRICs better understand the effectiveness of their financing.
} 
initiatives, such as the Extractive Industries Transparency Initiative (EITI) could help. $^{44}$

- $\quad$ Safeguarding debt sustainability. Macroeconomic analysis of total project financing, including assessments of risk, implications for public finances (including how maintenance costs will be financed and contingent liabilities associated with some FDI projects) and growth impact, is critical to avoid potential debt sustainability problems while ensuring adequate public investment. More broadly, borrowing decisions need to be made within a sound debt management strategy.

- Deepening project linkages to the local economy. LICs and BRICs could work together to build incentives, as part of a total package for development financing, to encourage local employment, foster skills development, and improve technology transfer. LIC governments and firms from development partners could work with local communities and workers to ensure labor regulations and work conditions are conducive to local employment. All in all, a more consultative and comprehensive approach is needed to address current concerns that could undermine long-term engagement between LICs and BRICs that should lead to huge benefits to both parties.

\section{CONCLUSION}

Though there are some differences across BRICs, the philosophies of most BRICs for development financing differ from traditional donors in three main ways: BRICs, with the exception of Russia, provide financial assistance based on the principle of 'mutual benefits' in the spirit of South-South cooperation, while Russia and traditional donors emphasize the role of aid in poverty reduction. Second, BRICs, particularly China, view policy conditionality as interfering with recipients' sovereignty and tend to provide noncash financing as a means to circumvent corruption, whilst traditional donors view policy conditionality as a means to ensure efficient use of aid. Third, different emphasis is placed on how to ensure debt sustainability, with some BRICs giving a greater weight to microsustainability and growth while traditional donors paying more attention to long-run macrosustainability. This difference is, however, narrowing with BRICs increasingly appreciating the importance of overall debt sustainability and traditional donors the need for investing in physical capital and seeing results.

\footnotetext{
${ }^{44}$ The importance of governance for safeguarding growth performance is particularly important for natural resource exporters, where often governance challenges are the greatest (Collier, 2000). The initiative provides a framework that both recipient countries and donors can use to foster greater transparency and accountability in awarding natural resource (and other) concessions.
} 
The public investment scale-up associated with BRIC development financing has benefited LICs by alleviating key infrastructure bottlenecks, boosting export competitiveness and making goods and services more affordable to consumers. Continued engagement with BRICs holds the potential to raise LICs' economic growth and reduce poverty in the long run. However, concerns have been raised over debt sustainability, pace of employment creation, labor practices, and competition with local firms. While none of these concerns is uniquely related to BRIC financing and has been debated in the past in relation to financing from other sources, they underscore the importance of managing the broader repercussions of the LIC-BRIC engagement.

As with other sources of financing, to maximize the benefits of LIC-BRIC cooperation, LICs will need to ensure high returns for BRIC-financed projects through sound public investment management. LICs and BRICs can work together to improve the transparency of project financing. This, together with a sound debt management strategy, would help minimize the debt-distress risks of increased borrowing. It would also be beneficial to all parties to deepen linkages between the BRIC-financed projects and the rest of the economy and encourage the employment of local workers. 


\section{REFERENCES}

African Center for Economic Transformation, 2009, "Looking East: China's Engagements with Africa Country Policymakers," Vol. II: Key Dimensions of ChineseEngagements in African Countries. Available via the internet: http://acetforafrica.org/publications/post/looking-east-chinas-engagements-withafrica-country-reports.

Adam, C., and D. Bevan, 2006, "Aid and the Supply Side: Public Investment, Export Performance, and Dutch Disease in Low-Income Countries," World Bank Economic Review, Oxford University Press, Vol. 20(2), pp. 261-290.

Agénor, P., and B. Moreno-Dobsen, 2006, "Public Infrastructure and Growth: New Channels and Policy Implications," World Bank Policy Research Working Paper No. 4064 (Washington: World Bank).

Alden, C., 2005, “China and Africa,” Survival, 47(3), 147-164.

Angola Press News Agency, 2006, “Comunicado do Conselho de Ministros,” February 22.

Anshan, L., 2007a, “China and Africa: Policy and Challenges,” China Security, 3(3), pp. 6993.

, 2007b, "Emerging Powers and their Development Policies: Case Study of China," presentation made at Emerging Powers and their Development Aid Policies, organised by SAIIA at Johannesburg, 29 October 2007.

Atingi-Ego, M., 2005, "Budget Support, Aid Dependency, and Dutch Disease: The Case of Uganda," World Bank Practitioners' Forum on Budget Support, May 5-6, Cape Town, South Africa.

Brautigam, D., 2010, The Dragon's Gift: The Real Story of China in Africa (Oxford University Press).

Calderón, C., 2009, "Infrastructure and Growth in Africa," World Bank Policy Research Working Paper No. 4914 (Washington: World Bank).

Campos, I., and A.Vines, 2008, Angola and China: A Pragmatic Relationship (New York: Centre for Strategic and International Studies).

Chaturvedi, S., 2008, "Emerging Patterns in Architecture for Management of Economic Assistance and Development Cooperation: Implications and Challenges for India," RIS Discussion Papers No. 139 (New Delhi, India: Research and Information System for Developing Countries).

Christensen, B. V., 2010, “China in Africa: A Macroeconomic Perspective," CGD Working Paper No. 230 (Washington: Center for Global Development). Available via the internet: http://www.cgdev.org/content/publications/detail/1424567. 
Claessens, S., Cassimon, D., and B. Van Campenhaut, 2007, "Empirical Evidence on the New International Architecture,” IMF Working Paper 07/277 (Washington: International Monetary Fund)

Collier, P., 2007, The Bottom Billion: Why the Poorest Countries are Failing and What Can Be Done About It (New York: Oxford University Press).

Council on Foreign Relations, 2005, "Our Common Interest: Report of the Commission for Africa," Commission for Africa (London, U.K.: Department for International Development).

Davies, M., H. Edinger, N. Tay, and S. Naidu, 2008, "How China Delivers Development Assistance to Africa," University of Stellenbosch (South Africa: Centre for Chinese Studies)

,2010, "Peer Review of China-Africa Papers for Special Issues of African Development Review," University of Stellenbosch (South Africa: Centre for Chinese Studies).

De Lorenzo, M., 2007, “African Perspective on China," American Enterprise Institute for Public Policy Research, October 3, 2007.

Easterly, W., Levine, R., and D. Roodman, 2004, “Aid, Policies, and Growth: Comment," American Economic Review, Vol. 94, No. 3, pp. 774-80.

Elu, J. U., and G. Price, 2010, "Does China Transfer Productivity Enhancing Technology to Sub-Saharan Africa? Evidence from Manufacturing Firms," African Development Review, Vol. 22, No. 1, pp. 587-598.

Freemantle, S., and J. Stevens, 2009, “Tectonic Shifts Tie BRIC and Africa's Economic Destinies," Standard Bank, Economics Africa: BRIC and Africa (October).

Forum on China Africa Cooperation (FOCAC), 2009, "Building the New Type of ChinaAfrica Stategic Partnership," $4^{\text {th }}$ Ministerial Conference on Forum on China-Africa Cooperation, Sharm El Sheikh, Egypt, November.

Foster, V., Butterfield, W., Chen, C., and N. Pushak, 2009, Building Bridges: China's Growing Role as Infrastructure Financier for Africa (Washington: World Bank). , and C. Briceño-Garmendia, 2010, Africa's Infrastructure: A Time for Transformation (Washington: World Bank).

Geda, A., and A. Meskel, 2008, "China and India's Growth Surge: Is it a Curse or Blessing for Africa? The Case of Manufactured Exports," African Development Review, Vol. 20, pp. 247-72. 
Githinji, M.W., 2010, "Is That a Dragon or Elephant on Your Ladder? The Potential Impact of China and India on Export-led Growth in African Countries," ed. by Seck and Boko, Back on Track: Sector-led Growth in African and Implication for Development, pp. 167-94 (Asmara, Eritrea: Africa World Press).

Goldstein, A., N. Pinaud, H. Reisen, and X. Chen, 2007, “The Rise of China and India: What's in it for Africa?" Development Centre (Paris: OECD).

IMF, 2010, "Emerging from the Global Crisis-Macroeconomic Challenges Facing LowIncome Countries." Available via the internet: www.imf.org/external/np/pp/eng/2010/100510.pdf

Infrastructure Consortium for Africa, 2008, Financial Commitments for Infrastructure in Africa for 2008 (Nairobi: Infrastructure Consortium for Africa).

Kiala, C., 2010, “The Impact of China-Africa Aid Relations: The Case of Angola," African Economic Research Consortium, Policy Brief No. 1 (November).

King, K., 2006, “Aid Within the Wider China-Africa Partnership: A View From the Beijing Summit," Available via the internet: http://www0.hku.hk/cerc/KK-article/4.ChinaAfrica\%20Partnership.King.2006d.pdf

Kragelund, P., 2010, “The Potential Role of Non-Traditional Donors' Aid in Africa," International Centre for Trade and Sustainable Development, Issue Paper No. 11 (February).

Li, R., 2007. “A Proper Understanding of Debt Sustainability of Developing Countries," World Economics and Politics Vol. 4, pp 63-73. , 2008, Chinese Finance in the Age of Globalization (Beijing: China Social Sciences Literature Press).

Lum, T., H. Fisher, J. Gomes-Granger, and R. Leland, 2009, “China's Foreign Aid Activities in Africa, Latin America, and Southeast Asia," (Washington: Congressional Research Service).

Mlachila, M., and M. Takebe, 2011, "FDI from BRICs to LICs," IMF Working Paper 11/178 (Washington: International Monetary Fund).

Mwanawina, I., 2008, “China-Africa Economic Relations: The Case of Zambia.” Available via the internet: $w$ ww.aercafrica.org/documents/china africa_relations/Zambia.pdf

Mwase, R. N., 1983, “The Tanzania-Zambia Railway: The Chinese Loan and the PreInvestment Analysis Revisited," The Journal of Modern African Studies, 21 (3), pp. 535-43.

, 1987, "Railway Pricing in Developing Countries: A Comparative Analysis," Journal of Transport Economics and Policy, 21(2), pp. 189-217. 
Mwase, N., 2011, "Determinants of Development financing flows from Brazil, Russia, India, and China to Low-Income Countries," IMF Working Paper 11/255 (Washington: International Monetary Fund).

Monson, J., 2006, "Defending the People's Railway in the Era of Liberalization: Tarazan in Southern Tanzania," Africa: The Journal of the International African Institute, 76 (1), pp. 113-30

Nyomi, T. S., 1998, "Foreign Aid and Economic Performance in Tanzania," World Development 26, pp. 1235-40.

Onjala, J., 2008, “A Scoping Study on China-Africa Economic Relations: The Case of Kenya," Available via the internet: http://www.aercafrica.org/documents/china_africa_relations/Kenya.pdf.

Prati, A., and T. Tressel, 2006, “Aid volatility and Dutch Disease: Is There a Role for Macroeconomic Policies?” IMF Working Paper 06/145 (Washington: International Monetary Fund).

Rajan, R. G., and A. Subramanian, 2008, “Aid and Growth: What Does the Cross-Country Evidence Really Show?” The Review of Economics and Statistics, 90 (4), pp. 643-65.

Reisen, H., and S. Ndoye, 2008, "Prudent Versus Imprudent Lending to Africa: From Debt Relief to Emerging Lenders," Working Paper No. 268 (Paris: OECD Development Centre).

Riad, N. and Y. Yang, 2012, "LIC-BRIC Trade Linkages: Trends and Implications for Growth," IMF Working Paper, forthcoming (Washington: International Monetary Fund).

Round, J., and M. Odedokun, 2004, "Aid Effort and its Determinants," International Review of Economics and Finance, pp. 293-309.

Russian Authorities, 2006, Position of the Russian Federation at 62 Session of the UN General Assembly. Availiable via the internet: http://www.un.int/russia/new/MainRoot/docs/interview/240807indexen.htm.

Russia's G8 Presidency, 2006, Russia and Issues Related to Aid to Africa in the Activities of the G8. Available via the internet: http://www.thailand.mid.ru/g8/01.html.

Sackey, H. A., 2001, "External Aid Flows and the Real Exchange Rate in Ghana," Research Paper 110 (Nairobi, Kenya: African Economic Research Consortium).

Samake, I., and Y. Yang, 2011, “Low-Income Countries' BRIC Linkage: Are There Growth Spillovers?” IMF Working Paper 11/267 (Washington: International Monetary Fund).

Sautman, B and Y. Hairong, 2009, "Trade, Investment, Power and the China-in-Africa Discourse," The Asia-Pacific Journal, 52(3). Available at: http://japanfocus.org/-YanHairong/3278 
Schiere, R., 2010, "Building Complementarities in Africa between Different Development Cooperation Modalities of Traditional Development Partners and China," African Development Review, Vol. 22 No. 1, pp. 615-628.

Smith, K., T. Fordelone, and F. Zimmermann, 2010, "Beyond the DAC: The Welcome Role of Other Providers of Cooperation," OECD Development Cooperation Directorate $(D C D-D A C)$ (Paris: OECD).

Straub, S., 2008, "Infrastructure and Development: A Critical Appraisal of the Macro Level Literature," Policy Research Working Paper Series 4590, (Washington: World Bank).

The Reality of Aid Network, 2010, South-South Development Cooperation: A Challenge to the Aid System? Report 2010 (Philippines: Reality Of Aid).

Tull, M. D., 2006, “China's Engagement in Africa: Scope, Significance and Consequences," Journal of Modern African Studies, 44(3), pp. 459-479.

United Nations Economic and Social Council, 2011, Draft $29^{\text {th }}$ April, Background Study for the 2012 Development Cooperation Forum: Trends in International Financial Cooperation for LDCs (Istanbul).

United Nations Millennium Project, 2005, Investing in Development. A Practical Plan to Achieve the Millennium Development Goals UNDP (U.K. and U.S.A.: Earthscan).

Vaz, A. C., and C. Inoue, 2007, "Emerging Donors in International Development Assistance: The Brazil Case." Available via the internet: www.norrag.org/issues/article/1330/en/brazil-in-africa.html

Vijava, K., T. Chahoud, and A. Kaushik, 2009, “India's Development Cooperation Opportunities and Challenges for International Development Cooperation," Briefing Paper 3 (Germany: DIE).

Wang, J. Y., 2007, “What Drives China's Growing Role in Africa?” IMF Working Paper 07/211 (Washington: International Monetary Fund).

World Bank, 1991, "The Challenge of Development," World Development Report 1991 (Oxford: Oxford University Press). , 2010, “The World Bank Annual Report 2010” (Washington: World Bank).

Yang, Y., 2011, “Global Rebalancing: Implications for Low-Income Countries,” IMF Working Paper, forthcoming (Washington: International Monetary Fund).

Yu, G., 1971, "Working on the Railroad: China and the Tanzania-Zambia Railway," Asian Survey, 99 (11), pp. 1101-1117. 